\title{
Deep Femoral Artery Branch
}

National Cancer Institute

\section{Source}

National Cancer Institute. Deep Femoral Artery Branch. NCI Thesaurus. Code C32437.

Any artery arising from the deep femoral artery. 